\title{
The hormonal control of ovine $\beta$-lactoglobulin gene in cultured ewe mammary explants
}

\author{
C Puissant, J Attal, LM Houdebine \\ INRA, Unité de Différenciation Cellulaire, 178350 Jouy-en-Josas, France \\ (Received 24 November 1989; accepted 17 January 1990)
}

Summary - Mammary explants from pregnant ewes were cultured in the presence of insulin, cortisol and prolactin, either alone, or in combination. After $2 \mathrm{~d}$ of culture, total RNA was extracted from explants and the content of $\beta$-lactoglobulin mRNA was estimated using a specific labelled cDNA probe. The mRNA for $\beta$-lactoglobulin was only deinduced slowly in the absence of hormone during the culture. Prolactin alone induced the accumulation of the mRNA. Insulin and cortisol added together were also stimulatory, but they only moderately amplified the prolactin effect. $\beta$-lactoglobulin gene in ewes, is therefore, controlled by the lactogenic hormones which also induce casein gene expression. The amplitude of the stimulation was unexpectedly low. This seems due in part to the fact that the gene was only deinduced weakly. In this respect, $\beta$-lactoglobulin gene appears to be less dependent on lactogenic hormones under these experimental conditions than casein genes.

\section{ß-lactoglobulin / ovine / hormonal control /mammary explants culture}

Résumé - Le contrôle hormonal du gène de la $\beta$-lactoglobuline ovine dans des cultures d'explants mammaires de brebis. Des explants mammaires de brebis ont été cultivés en présence d'insuline, de cortisol et de prolactine, seuls ou associés. Après 2 jours de culture, l'ADN total a été extrait des explants et le contenu en ARNm de $\beta$-lactoglobuline a été estimé en utilisant une sonde $A D N c$ marquée spécifiquement. L'ARNm de la $\beta$-lactoglobuline n'est que lentement déinduit pendant les 2 jours de culture. La prolactine seule induit l'accumulation de l'ARNm. L'insuline et le cortisol, ajoutés ensemble, ont un pouvoir stimulant mais ils n'amplifient que modérément l'effet de la prolactine. Le gène de la $\beta$-lactoglobuline chez la brebis est donc contrôlé par les hormones lactogènes qui induisent aussi l'expression des gènes des caséines. L'amplitude de l'induction s'est avérée plus faible que prévu. Ceci semble en partie du au fait que le gène n'est que partiellement déinduit. A cet égard, le gène de la $\beta$-lactoglobuline ovine apparaît moins dépendant des hormones lactogènes que ceux des caséines dans ces conditions expérimentales.

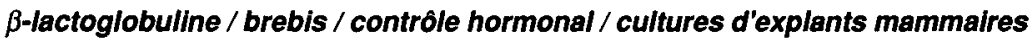

\footnotetext{
" Correspondence and reprints
} 


\section{INTRODUCTION}

Milk protein genes are known to be controlled by several hormones including prolactin, cortisol, insulin and progesterone (Houdebine, 1986). Cultures of mammary explants carried out in rat (Hobbs et al, 1982), rabbit (Devinoy et al, 1988), ewe (Houdebine et al, 1985), mouse (Banerjee and Antoniou, 1985) and cow (Shamay et al, 1988) have shown that, in all cases, prolactin, insulin and cortisol stimulate, whereas progesterone inhibits, milk protein gene expression. $\beta$-lactoglobulin gene which exists in a limited number of species, including sheep and cow, was isolated and its structure defined (Gaye et al, 1986; Ali and Clarck, 1988). Experiments carried out in vivo have shown that $\beta$ lactoglobulin mRNA in the pregnant ewe is accumulated under the influence of glucocorticoids (Gaye et al, 1986). Moreover, ovine $\beta$-lactoglobulin gene was expressed abundantly and specifically in the mammary gland of transgenic mice (Simons et al, 1987). The data reported here reveal how the ovine $\beta$-lactoglobulin gene is controlled by hormones in cultured ewe mammary explants.

\section{MATERIALS AND METHODS}

\section{Explants culture}

Fragments of mammary tissue explanted from 95-d pregnant ewes were cultured in medium 199 without serum for $2 \mathrm{~d}$ under $95 \% \mathrm{O}_{2}$ and $5 \% \mathrm{CO}_{2}$ essentially, as previously described (Houdebine et al, 1985). About $800 \mathrm{mg}$ of tissue was used for each hormonal combination, the medium contained no hormone or combinations of ovine prolactin (NIH PS13) $(1 \mu \mathrm{g} / \mathrm{ml})$, cortisol $(500 \mathrm{ng} / \mathrm{ml})$ and bovine insulin $(5 \mu \mathrm{g} / \mathrm{ml})$. Three independent cultures were performed from 3 different animals.

\section{Extraction of RNA}

At the end of culture, the tissue was collected and kept frozen until use. Total RNA was extracted using the method of Chomsczkinsky and Sacchi (1987) with slight modifications (Puissant and Houdebine, 1990). Briefly, the frozen tissue was homogenized in a solution of guanidinium isothiocyanate and RNA was directly extracted in the presence of phenol and chloroform, as described (Chomsczkinsky and Sacchi, 1987). The RNA pellet, obtained after the precipitation by isopropanol, was resuspended in $2 \mathrm{M} \mathrm{LiCl}$ to solubilize polysaccharides. The pellet was redissolved in $0.5 \%$ sodium dodecylsulphate and RNA was extracted in the presence of chloroform. The same method was used to extract RNA from fresh mammary tissue of a 118-day pregnant ewe.

\section{Measurement of $\beta$-lactoglobulin mRNA}

RNA $(20 \mu \mathrm{g})$ was denatured by formaldehyde at $65^{\circ} \mathrm{C}$ as described by Thomas (1980). The denatured RNA was diluted in $300 \mu 110 \times$ SSC and layered over $1 \mathrm{~cm}^{2}$ Zeta probe nylon filter. RNA retained on the filter was fixed by UV light irradiation (Khandjian, 1986). Prehybridization and hybridization were carried out in $0.5 \mathrm{M}$ phosphate buffer (Mahmoudi and Lin, 1989) containing $0.5 \%$ non-fat dry milk instead of bovine serum albumin. The probe was ovine $\beta$ lactoglobulin 32P cDNA (Gaye et al, 1986) labelled by oligolabelling $\left(10^{9} \mathrm{cpm} / \mu \mathrm{g}\right.$ DNA). The hybridization medium contained $800000 \mathrm{cpm} / \mathrm{ml}$ of the probe. After overnight hybridization, the filters were washed extensively in $50 \mathrm{mM}$ phosphate buffer (Mahmoudi and Lin, 1989). Each filter was then placed in a vial in the presence of a scintillation mixture and the hybridized probe was evaluated by a $\beta$ scintillation counter. Each result is the mean of triplicates.

Northern blot analysis were carried out by a conventional method. $20 \mu \mathrm{g}$ RNA were added in each well of agarose gel after a denaturation in a mixture of formaldehyde and formamide. At the end of the electrophoresis, RNA was transferred to Zeta probe filters by capillarity in water. Hybridization was carried out as described above. 


\section{RESULTS}

Milk protein gene expression can be easily evaluated using radioimmunoassay which specifically measure the accumulation of milk proteins in cultured mammary explants (Houdebine et al, 1985). Experiments, not shown here, indicated that $\beta$ lactoglobulin was present at a relatively high level even in the fresh and unstimulated tissue, indicating that the background expression of $\beta$-lactoglobulin gene in midpregnant ewes is sufficient to accumulate rather large amounts of the protein in the mammary gland. For this reason, the $\beta$ lactoglobulin radioimmunoassay could not be used since the amount of $\beta$ lactoglobulin synthesized under the hormonal stimulation in vitro was negligible in comparison to the quantity synthesized and stored before the culture. Measurements of $\beta$-lactoglobulin mRNA are not expected to suffer from this limitation. As a matter of fact, mRNA in a cell is simultaneously synthesized and degraded to reach a steady state, whereas secreted milk proteins can be stored in the lumen of mammary alveoli over long periods of time in an essentially undegraded form even after their synthesis has ceased. Moreover, mRNA accumulation, resulting from both a specific activation of transcription and a stabilization of the transcripts, is more directly related to the mechanism of action of hormones. For these reasons, measurement of $\beta$-lactoglobulin mRNA concentration, rather than radioimmunoassay of the protein, was chosen to determine the effects of lactogenic hormones on $\beta$ lactoglobulin gene expression.

Increasing amounts of RNA extracted from the mammary gland of a 118-day pregnant ewe was loaded on filters and hybridized to the probe. In figure 1, it can be seen that the hybridized probe was essentially linear up to $50 \mu \mathrm{g}$ RNA per filter. In the following experiments, $20 \mu \mathrm{g}$ RNA were used.

Three cultures were carried out independently. Prolactin alone doubled the concentration of $\beta$-lactoglobulin mRNA. This stimulation was relatively modest and at best, slightly amplified by insulin or cortisol added with prolactin. The combination of the 3 hormones was not more potent than prolactin alone. On the other hand, the association of insulin and cortisol doubled the concentration of $\beta$-lactoglobulin mRNA, even in the absence of prolactin. Cortisol appeared poorly active in the absence of insulin either alone, or associated with prolactin. In all cases, the stimulation by hormones remained very limited and it did not exceed 2-fold (fig 2). Statistical analysis of the results indicated that the following hormonal combinations: PRL, I +

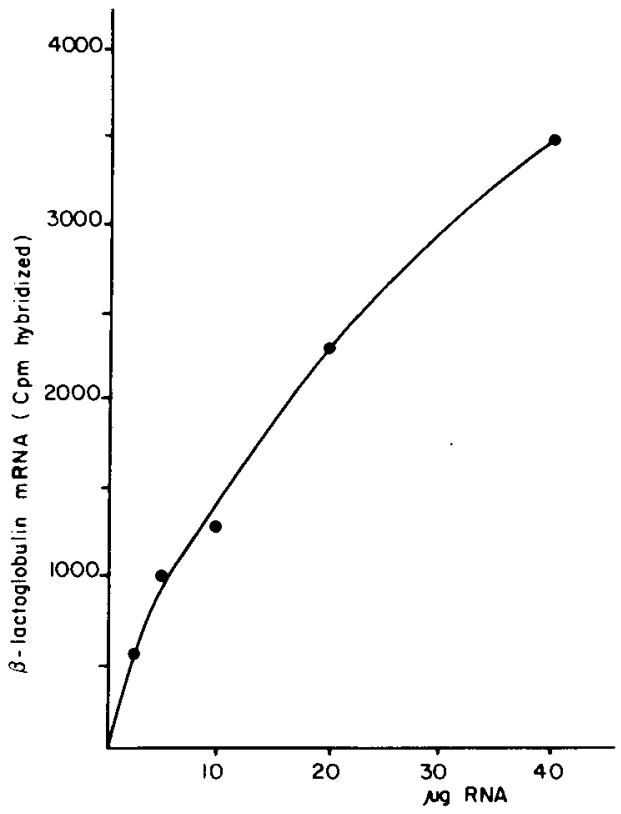

Fig 1. Hybridization of $\beta$-lactoglobulin CDNA probe with increasing amounts of total RNA extracted from the mammary gland of a $118 \mathrm{~d}$ pregnant ewe. Results are the means of duplicates. 


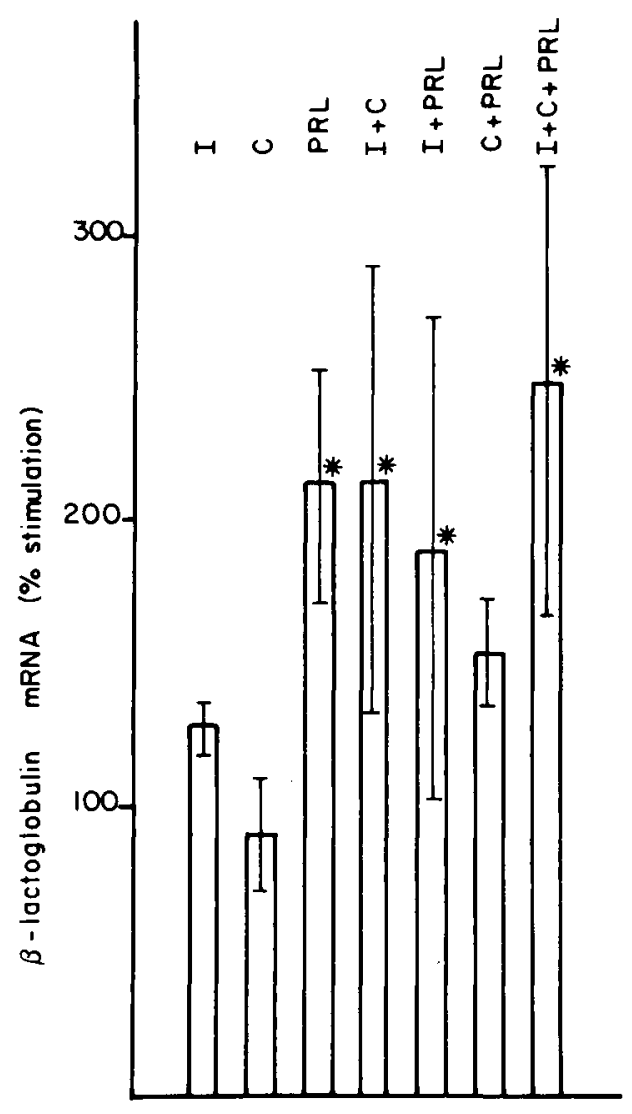

Fig 2. Effect of various hormonal combination on the accumulation of $\beta$-lactoglobulin mRNA. $20 \mu \mathrm{g}$ of RNA were used in all cases. Results are the means ( \pm SEM) of 3 independent cultures. They are expressed as the percentage of stimulation referring to the values obtained without hormone taken as $100 \%$ in each culture. 'I: insulin; C: cortisol; PRL: prolactin. * Significantly higher than control $(P<0.05)$.

C, I + PRL and I + C + PRL were all significantly higher than the control without hormone (with $P<0.05$ ). On the contrary, the combinations I, C, C + PRL were not significantly different from the control. No significant differences emerged between the stimulating combinations. More experi- ments should have been performed to point out possible subtle modulations by the different hormones. This did not appear justified, given the low amplitude of the maximum stimulation in these experimental conditions.

These results were essentially confirmed by Northern blotting in which the same RNA were used. Results shown in figure 3 indicate that insulin, cortisol and prolactin participate in the stimulation of $\beta$ lactoglobulin gene expression. These effects can be considered as specific since actin mRNA proved not to be sensitive to lactogenic hormones (fig 3 ).

\section{DISCUSSION}

The data reported here indicate that ovine $\beta$-lactoglobulin gene expression is stimulated by the essential lactogenic hormones; insulin, cortisol and prolactin as the other milk protein genes (Hobbs et al, 1982; Banerjee and Antoniou, 1985; Houdebine et al, 1985; Houdebine, 1986; Devinoy et al, 1988; Shamay et al, 1988). However, $\beta$ lactoglobulin gene appears to be regulated somewhat differently. The $\beta$-lactoglobulin gene, such as casein genes from rabbit (Devinoy et al, 1988) and ewe (Houdebine et al, 1985), are sensitive to prolactin alone. Insulin and cortisol, which exert a minor effect in the absence of prolactin on casein gene, are known to be potent amplifiers of prolactin action (Hobbs et al, 1982; Banerjee and Antoniou, 1985; Houdebine et al, 1985; Houdebine, 1986; Devinoy et al, 1988; Shamay et al, 1988). In the experiments depicted here, insulin and cortisol appear to have a limited amplificatory effect on prolactin action. Cortisol tends to have an inhibitory effect on $\beta$-lactoglobulin gene, whereas the same concentration of the hormone $(500 \mathrm{ng} / \mathrm{ml})$, also in ewe, clearly stimulates $\beta$-casein synthesis in vi- 


\section{$\beta$-Lactoglobulin $\rightarrow$}

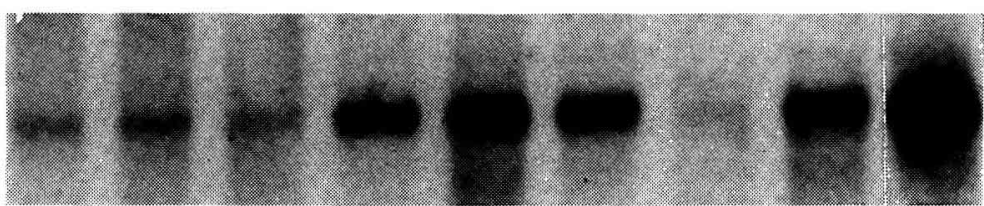

(3)
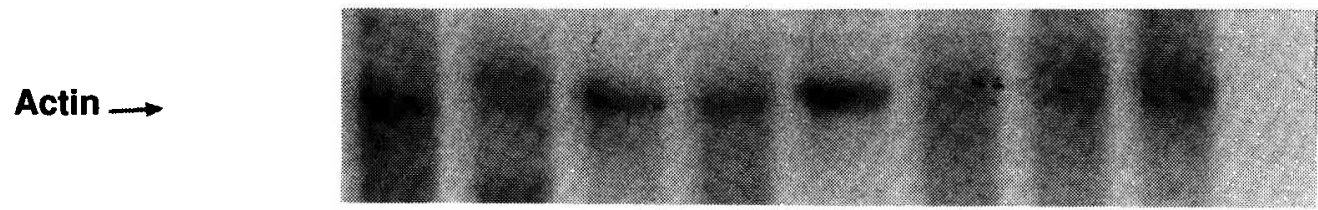

Fig 3. Northern blot of RNA extracted from cultured mammary tissue. $20 \mu \mathrm{g}$ were added in each well. A) Hybridization with $\beta$-lactoglobulin cDNA probe.

B) Hybridization of the same blot with $\beta$-actin CDNA probe after a dehybridization of $\beta$-lactoglobulin cDNA probe in boiling water. RNA from fresh tissue was not present during hybridization with the actin probe.

tro (Houdebine et al, 1985). Cortisol associated with insulin significantly stimulated in vitro $\beta$-lactoglobulin $\mathrm{mRNA}$ accumulation; a fact in good agreement with in vivo experiments (Gaye et al, 1986).

The most striking fact, is the relatively poor stimulation of $\beta$-lactoglobulin gene expression in our experimental conditions. In quite similar experimental conditions, $\beta$ casein gene in the ewe (Houdebine et al, 1985), $\alpha$ and $\beta$ casein genes in the rat (Hobbs et al, 1982) and $\alpha$ and $\beta$-casein gene in the rabbit (Devinoy et al, 1988,
1989) are heavily stimulated (up to 250fold for $\beta$-casein in the rat and 50 -fold for $\alpha$-casein in the rabbit). $\beta$-lactoglobulin gene thus appears clearly different from casein genes. It is only slowly deinduced in the absence of hormone during the $2 d$ of culture, as opposed to casein genes (Hobbs et al, 1982; Devinoy et al, 1988). Hence, although it is expressed at a high leve,l it is modestly stimulated by the hormones. These facts are reminiscent of observations done for another major milk, protein gene, the gene for whey acid protein (WAP) which, like $\beta$-lactoglobulin, is 
expressed in some mammalian species only. WAP is known to be expressed in rodent's milk, but not exclusively, whereas $\beta$ lactoglobulin is expressed in ruminant's milk although not exclusively. No clear correlations appear in this respect between the 2 genes. Experiments carried out in rat (Hobbs et al, 1982), rabbit (Devinoy et al, 1988, 1989) and mouse (Pittius et al, 1987) have shown that the WAP gene is also controlled by insulin, cortisol and prolactin. However, prolactin alone is unable to induce WAP gene expression in the rabbit, whereas a combination of insulin and cortisol or prolactin and cortisol, proved efficient (Devinoy et al, 1988, 1989). On the other hand, in vitro experiments pointed out that the WAP gene is only weakly deinduced in vitro in the absence of hormone, and rather modestly stimulated by insulin, cortisol and prolactin (Hobbs et al, 1982; Devinoy et al, 1988, 1989). In vivo, both WAP and $\beta$-lactoglobulin genes are markedly stimulated throughout the pregnancy-lactation cycle (Gaye et al, 1986; Pittius et al, 1987; Busso et al, 1989; Devinoy et al, 1989). This fact is somewhat different from the in vitro situation. It is, however, not completely surprising since the level of milk protein gene expression in vitro never reaches the in vivo level. It suggests that, in vivo, and not in vitro in most of the experimental conditions (Hobbs et al, 1982; Banerjee and Antoniou, 1985; Houdebineet al, 1985; Houdebine, 1986; Devinoy et al, 1988; Shamay et al, 1988), progesterone strongly repress, WAP and $\beta$-lactoglobulin genes, such as casein genes. The marked effect of cortisol injections on the expression of $\beta$-lactoglobulin gene in pregnant ewes (Gaye et al, 1986) might result, at least in part, from a competition between progesterone and cortisol.

It is, of course, difficult to speculate on the mechanism of action of lactogenic hormones on milk protein genes as long as their promoters are not known in more detail. It is tempting, however, to imagine that casein genes, which are the typical milk protein genes expressed abundantly and exclusively in the mammary gland of all mammals, have gained a strong and specific hormonal regulation during evolution. On the contrary, WAP and $\beta$ lactoglobulin genes, which are members of gene families expressed in tissues other than the mammary gland, may be considered as "occasional" milk protein genes. Their regulation in the mammary gland may have been reduced to a minimum: specific expression in the mammary gland and repression in non-lactating females. Further studies on promoter structure and function are, of course, necessary to establish whether this hypothesis is correct.

\section{ACKNOWLEDGMENTS}

The authors wish to thank Dr P Gaye for providing the $\beta$-lactoglobulin CDNA and Dr M Buckingham for providing the acting cDNA. This work was supported with the financial assistance of the Biotechnology Action Programme of the European Community.

\section{REFERENCES}

Ali S, Clark AJ (1988) Characterization of the gene encoding ovine beta-lactoglobulin. $J$ Mol Biol 199, 415-426

Banerjee MR, Antoniou M (1985) Steroid and polypeptide hormone interaction in milk protein gene expression. In: Biochemical Actions of Hormones, Academic Press Inc, Vol XII, 237-288

Busso N, Huarte J, Vassalli JD, Sappino AP, Belin D (1989) Plasminogen activators in the mouse mammary gland. $J$ Biol Chem 264 , 7 455-7 457

Chomsczhinsky P, Sacchi N (1987) Single-step method of RNA isolation by acid thiocyanatephenol-chloroform extraction. Anal Biochem $162,156-160$ 
Devinoy E, Hubert C, Jolivet G, Thepot D, Clergue N, Desaleux M, Dion M, Servely JL, Houdebine LM (1988) Recent data on the structure of rabbit milk protein genes and on the mechanism of the hormonal control of their expression. Reprod Nutr Dev 28, 1145-1 164

Devinoy E, Jolivet G, Thepot D, Houdebine LM (1989) Prolactin control of rabbit protein gene expression in the rabbit mammary gland. 8th Workshop on Development and Function of the Reproductive Organs. Serono Symp Rev $21,21-36$

Gaye P, Hue-Delahaie D, Mercier JC, Soulier S, Vilotte JL, Furet JP (1986) Ovine $\beta$ lactoglobulin messenger RNA: nucleotide sequence and mRNA levels during functional differentiation of the mammary gland. Biochimie 68, 1 097-1 107

Hobbs AA, Richards DA, Kessler DJ, Rosen JM (1982) Complex hormonal regulation of rat casein gene expression. J Biol Chem 257, 3 598-3 605

Houdebine LM (1986) Contrôle hormonal du développement et de l'activité de la glande mammaire. Reprod Nutr Dev 26, 523-541

Houdebine LM, Djiane J, Dusanter-Fourt I, Martel P, Kelly PA, Devinoy E, Servely JL (1985) Hormonal action controlling mammary activity. J Dairy Sci 68, 489-500
Khandjian EW (1986) UV crosslinking of RNA to nylon membrane enhances hybridization signals. Mol Biol Rep 11, 107-115

Mahmoudi M, Lin VK (1989) Comparison of two different hybridization systems in Northern transfer analysis. Biotechniques 7, 331-333

Pittius CW, Sankaran L, Topper YJ, Hennighausen $L$ (1987) Comparison of the regulation of the whey acidic protein gene with that of a hybrid gene containing the whey acidic protein gene promoter in transgenic mice. Mol Endocr 2, 1 027-1 032

Puissant C, Houdebine LM (1990) An improvement of the single-step method of RNA isolation by acid guanidium thiocyanate-phenolchloroform extraction. Biotechniques 8, 148149

Shamay A, Cohen A, Niwa M, Gertler A (1988) Effect of insulin-like growth factor I on deoxyribonucleic acid synthesis and galactopoiesis in bovine undifferenciated and lactating mammary tissue in vitro. Endocrinology 123, 804809

Simons JP, McClenaghan M, Clark AJ (1987) Alteration of the quality of milk by expression of sheep $\beta$-lactoglobulin in transgenic mice. Nature 328, 530-532

Thomas P (1980) Hybridization of denaturated RNA and small DNA fragments transferred to nitrocellulose. Proc Natl Acad Sci USA 77, $5201-5204$ 